BULLETIN Bulletin hispanique

HISPANIQUE Université Michel de Montaigne Bordeaux

123-1| 2021

La forma de vida cortesana en la literatura de la Edad Media y el Siglo de Oro

\title{
Cortesía y cortesanía en la literatura medieval y áurea
}

José Julio Martín Romero

\section{(2) OpenEdition}

\section{Journals}

Edición electrónica

URL: https://journals.openedition.org/bulletinhispanique/12034

DOI: 10.4000/bulletinhispanique.12034

ISSN: 1775-3821

\section{Editor}

Presses universitaires de Bordeaux

\section{Edición impresa}

Fecha de publicación: 20 junio 2021

Paginación: 9-13

ISBN: 979-10-300-0697-1

ISSN: 0007-4640

Referencia electrónica

José Julio Martín Romero, «Cortesía y cortesanía en la literatura medieval y áurea», Bulletin hispanique [En línea], 123-1 | 2021, Publicado el 20 junio 2021, consultado el 02 julio 2021. URL: http://

journals.openedition.org/bulletinhispanique/12034 ; DOI: https://doi.org/10.4000/bulletinhispanique. 12034 


\title{
La cortesanía verbal en los libros de caballerías: el caso de Belianis de Grecia
}

\author{
José Julio Martín Romero \\ Universidad de Jaén
}

Este artículo analiza la importancia de los aspectos verbales en el comportamiento cortesano en Belianís de Grecia, un libro de caballerías escrito por Jerónimo Fernández. El estudio determina los rasgos corteses de expresión verbal y muestra que (al igual que los mencionados en el libro de Castiglione) derivan de la cortesía medieval.

Palabras clave: Libros de caballerías, Jerónimo Fernández, comportamiento cortesano, cortesanía verbal.

\section{La courtoisie verbale dans les livres de chevalerie : le cas de Belianís de Grecia}

L'article analyse l'importance de la composante verbale du comportement courtois dans Belianis de Grecia, un roman de chevalerie écrit par Jerónimo Fernández. L'étude définit les traits courtois d'expression verbale et montre (comme pour ceux que mentionne le livre de Castiglione) qu'ils proviennent de la courtoisie médiévale.

Mots-clés: Livres de chevalerie, Jerónimo Fernández, comportement courtois, courtoisie verbale.

\section{Verbal courtesy in chivalry books : the case of "Belianis de Grecia"}

This article analyses the importance of verbal aspects of courtly behavior, focusing on "Belianis de Grecia", a chivalry novel written by Jerónimo Fernández. This study determines the main features of courtly verbal expression and shows that -just as those mentioned in Castiglione's book- these features derived from medieval courtoisie.

Keywords: Chivalry books, Jerónimo Fernández, courtly behaviour, courtly verbal expression. 


\section{CORTESÍA Y CORTESANÍA*}

Es sabido que los libros de caballerías, herederos de la literatura artúrica, asumieron la cortesía como ideal de conducta; esta no solo afecta a las relaciones amorosas, sino que se trata de todo un código de comportamiento social basado en una elegancia y sofisticación, solo al alcance de la clase superior que vive en la corte -de donde deriva el término- y, por tanto, separada del pueblo ${ }^{1}$.

En los libros de caballerías la corte no siempre es meramente un punto de partida o destino de la andadura caballeresca, sino que se convierte en verdadero escenario de aventuras que en muchas ocasiones presentan tintes mágicos o espectaculares con una buena dosis de teatralidad (Río Nogueras 1995 y 2004). Pero lo cortesano no se limita únicamente a este espacio, sino que forma parte de la propia esencia de sus personajes, que, en tanto que nobles, se han de mostrar corteses. Este comportamiento suponía una cierta de mascarada y tenía bastante de representación teatral, en tanto que el hablante se presenta como siervo del interlocutor. Hay así un factor de juego cortesano $\mathrm{y}$ de fingimiento consciente ${ }^{2}$.

En este sentido, cortesía y cortesanía parecen confundirse; si bien, en los siglos XVI y XVII el término "cortesía» se utilizó muchísimo más que "cortesanía»" en plural indicaban el juego de gestos ceremoniosos, las palabras y las reverencias obsequiosas y, en general, aquellas conductas sofisticadas propias de la corte ${ }^{4}$. Se tiende a pensar que el tratado de Castiglione ofrece la

* Este trabajo se ha realizado en el marco del equipo de investigación EI_HUM6_2019 (Investigador principal: José Julio Martín Romero) de la Universidad de Jaén.

1. "les termes de courtois et de courtoisie tantôt désignent, dans un sens large, la générosité chevaleresque, les élégances de la politesse mondaine, une certaine manière de vivre, et tantôt dans un sens plus restreint, un art d'aimer inaccesible au commun des mortels" (Frappier: 3). Barber (71) también considera que la cortesía es un concepto más amplio y anterior al amor cortés: «Courtly manners are the essencial prelude to courtly love». Por su parte, Elias valora las relaciones entre el término cortesía, y otros utilizados para definir los rasgos de civilización a lo largo de la historia.

2. "courtly manners became theatrical and affected, and courtly fashions extravagant and exaggerated》 (Barber: 71).

3. En realidad, hasta el siglo XV el término «cortesanía» apenas se utiliza. Sí lo hace Alonso de Palencia en una ocasión en su Universal vocabulario en latín y en romance, donde lo vincula con burlas y juegos: «Iocus es dulçe burla \& cortesania \& palabras de riso» (s. v. iocari) (fol. 223v). Asimismo, relaciona "cortesía» con las facecias: «Facetie son dichos o fechos en que hay dulçor o suauidad de palabras que dizen cortesia» (s. v. facetus) (fol. 151v).

4. En cuanto a "cortesano", en su Tesoro de la lengua castellana o española de 1611 Covarrubias lo definió, por una parte, como el dedicado a la vida de la corte, al servicio, y, por otra, en tanto que se le presuponía una serie de rasgos, también al que mostraba tener estas cualidades. Esos rasgos, según este lexicógrafo, no eran sino ser «muy discretos y avisados» $(619$, s. v. corte), y tener «hidalgo término y honrado trato» $(619$, s. v. corte). Frente al tratado de Castiglione, el Tesoro parece recoger una tradición más típicamente española, centrada en aspectos de tipo moral más que de etiqueta cortesana, como se revela en las críticas de Castillejo, las obras de Guevara o, ya en el siglo XVII, del propio Baltasar Gracián. No obstante, el influjo del italiano se mezcla con esa visión hispánica y se hace más evidente en la obra de Luis de Milán. No me detendré en este punto; aún sigue siendo muy interesante el trabajo de Morreale sobre este tema. 
mejor definición de cortesanía, y lo es si tenemos en cuenta que se refiere a un determinado tipo, aquella que es «más convenible a un gentil cortesano que ande en una corte para que pueda y sepa perfectamente servir a un príncipe en toda cosa puesta en razón» (77); por tanto, el italiano no pretendía definir el término en su conjunto, sino un hipónimo de este: aquella cortesanía más adecuada al siervo5. Ese comportamiento, según Castiglione, requería, como es lógico, mostrarse siempre solícito, humilde y obediente a los deseos de aquel a quien se sirve ${ }^{6}$. Pero no hay que olvidar que, además, el servidor debía abandonar cualquier rastro de actitud plebeya, por lo que sigue un proceso de imitación de los modales aristocráticos (esto es, corteses) de su señor ${ }^{7}$.

En el siglo XV Alonso de Cartagena distinguía entre la cortesía -hacia quienes no se tiene obligación de obedecer- y la sumisión o sujeción -del siervo hacia su señor-, y explicaba que quien se negaba a besar el pie al Papa o al rey, no es descortés, sino rebelde (92). Por tanto, lo que en el señor es pose civilizada en el siervo es obligación. A pesar de esa diferencia, lo cierto es que esos rasgos de humildad, y de sumisión -propios de quien sirve- son los que proponía la cortesía, como gesto mundano y sofisticado, de manera que la realidad de la sumisión del siervo y la sofisticación de la sumisión cortés coinciden y se confunden en las normas propuestas por Castiglione $e^{8}$. De esta forma, se difuminan los límites entre las formas de humildad real, debidas a la función de servidor, y la imitación de las formas nobiliarias, es decir, la pose cortés. Eso explica que en el siglo XVII Alonso Núnez de Castro, cronista de Felipe IV, en Libro histórico político. Solo Madrid es corte y el cortesano en Madrid, estableciera como "primera virtud del cortesano, la cortesía» (fol. 57v). Si el siervo quiere medrar, ha de ofrecer una imagen de un estatus social más alto del que le corresponde, y eso implica la mímesis de comportamientos aristocráticos (esto es, corteses) con su falsa sumisión.

5. Recomendamos el estudio de Quondam (2013) sobre los términos italianos.

6. Recordemos las indicaciones de Guevara en su Aviso de privados y doctrina de cortesanos. Especialmente significativo a nuestro propósito es el capítulo V («De la manera que ha de tener y de las ceremonias que ha de hacer el cortesano cuando al Rey ha de hablar», fol. 48r) en el que se observa la humildad que ha de mostrar en esa situación, humildad necesaria en tanto que siempre será un ser inferior jerárquicamente al soberano.

7. González Ollé indicó en su estudio sobre el habla cortesana que la cortesanía implicaba la necesidad de imitar a los nobles: «Todo el que acude, en cualquier tiempo y lugar, voluntariamente, a la corte o centro análogo, lo hace con la pretensión de alcanzar algún beneficio [...] Se impone, pues, en muchos aspectos del trato, la imitación. Requisito indispensable es hacerse entender; [...] procurar la adecuación lingüística facilita la acogida» (157).

8. El hecho de que Cartagena hubiera de definir esa diferencia implica que la confusión ya existía en el siglo XV; no es extraño que se produjera, las directrices fundamentales de modales propuestos por Castiglione no se alejan de lo que Crouch considera "cortés»: «what was called in French courtois or in Latin curialius. This meant that they had to have a confident and amiable way with other people, great and small alike, and not needlessly antagonise their fellow courtiers. To avoid envy, they had always to be modest about their talents and achievements, however great they were» (150). 
En los libros de caballerías encontramos ambas circunstancias: siervos (escuderos, criados, doncellas, etc.) que se muestran como cortesanos al servicio de sus señores; pero también ese juego de humildad sofisticada, esa mascarada social entre personajes pertenecientes a los estratos más altos. También estos se presentan como sumisos, mesurados y dispuestos siempre al servicio. Siempre se ha de tener presente que por parte de los nobles todas esas palabras y gestos forman parte de la convención, de la ceremonia, de una etiqueta social que requiere un cierto grado de fingimiento?

\section{LA CORTESANÍA DEL HABLAR}

En la conducta cortesana, la importancia de la expresión verbal -vinculada en ocasiones con las reflexiones sobre la lengua- no se escapaba a los pensadores de esos años, por lo que los tratados de cortesanía no olvidaban esos aspectos. En Italia la fama de Il Cortegiano de Castiglione -cuya influencia en la tradición española mediante la traducción de Boscán fue enorme-afianzó la importancia dada a la forma de hablar, lo que justifica que se redactaran textos como $\mathrm{La}$ civil coversazione de Stefano Guazzo o La corteggiania de Strozzi. En España esa preocupación por saber comportarse en la corte propició la aparición de textos como el Aula de cortesanos de Cristóbal de Castillejo, el Aviso de privados y doctrina de cortesanos de Antonio de Guevara el Cortesano de Luis de Milán o el Galateo español de Lucas Gracián Dantisco, por citar tan solo algunos. En todos estos se hacía hincapié en la necesidad no solo de saber qué decir, sino también de cómo y cuándo hablar ${ }^{10}$. Luis de Milán considera que «el caballero armado virtuoso es la mejor criatura de la tierra, y para tener perfecta mejoría debe ser cortesano, que es en toda cosa saber bien hablar y callar donde es menester» (2). Obsérvese que define «ser cortesano» como «saber bien hablar y callar» ${ }^{11}$. Por ello, compone su libro que «Dá modos y avisos de hablar sin verbosidad, ni afectacion, ni cortedad de palabras que sea para esconder la razón, dando conversaciones para saber burlar á modo de palacio» $(5)^{12}$. En

9. Se trata del «gusto por la ingeniosidad y la agudeza que anidaba en las formas sociales cortesanas, y la exigencia de otras facultades en el caballero al margen del dominio de las artes guerreras», en palabras de Río Nogueras (1993: 76).

10. No obstante, los tratados españoles muchas veces están teñidos de connotaciones morales que los vinculan con la tradición sapiencial y gnómica. Por tanto, no siempre se trata solo de ofrecer modelos para sobrevivir y medrar en la corte, sino también reglas de bien obrar. Curiosamente, no son estas reglas las mejores para sobrevivir en el ambiente cortesano, pues, entre otras cosas, se rechaza la mentira; así Guevara afirma en el capítulo XX de su Aviso de cortesanos «que los privados de los príncipes deven sobre todas cosas mucha verdad tractar y por cosa de las del mundo jamás una cosa por otra dezir» (164r). En tanto que este autor habla de privados y consejeros, es comprensible que propugne la necesidad de evitar la mentira. Esa misma orientación se observa en las obras de Alonso de Barros o del mismo Gracián (sobre las diferencias de la «cortesanía» entre Castiglione y Baltasar Gracián, Ricci).

11. Sobre la importancia del silencio en la vida cortesana, Orduna Portús.

12. En otra ocasión se lee: «La intincion mia en este Cortesano ha sido representar todo lo 
este punto continúa la tradición de Castiglione, que afirmaba la necesidad de que la conversación del cortesano fuera sensata y agradable, así como de que se adecuara a diversas circunstancias, desde las más solemnes hasta las más distendidas.

Por tanto, en el pensamiento de la época se concedía gran importancia a la conversación y a la expresión cortés y ello porque la forma de hablar se entendía como un signo de estatus social.

\section{LA CORTESANÍA VERBAL Y LOS LIBROS DE CABALLERÍAS}

Esas visiones fundamentalmente teóricas de la expresión verbal y del arte del diálogo no pueden entenderse sin el estudio de su realización práctica en los textos escritos. Ravasini señaló las coincidencias entre las orientaciones en El Cortesano de Luis de Milán y los diálogos de la Cuestión de amor (81) ${ }^{13}$. De igual manera, los libros de caballerías ofrecían a los lectores de la época útiles ejemplos de cortesanía en el hablar. Marco Antonio de Camos, en su Microcosmía y gobierno universal del hombre christiano para todos los estados y qualquiera de ellos (2-3), afirmaba que «los cuatro de Amadis era opinión de viejos que enseñavan un cortés trato y lenguaje que deven usar los cavalleros (cómo han de guardar su palabra y cuán leales han de ser, con las demás cosas a este talle)». Como recuerda González Ollé (153), en el Quijote (I, 6) se comentaba esa utilidad en Palmerín de Inglaterra, al hablar de sus «razones, cortesanas y claras, que guardan y miran el decoro del que habla» ${ }^{14}$.

Por tanto, se hace necesario estudiar esos juegos cortesanos verbales en los textos caballerescos para comprender a qué se referían los tratados teóricos ${ }^{15}$.

que en cortes de príncipes se trata: diversidad de lenguas, por las diversas naciones que suele tener; uso de todos los estilos, usando del altíloco en las cosas altas, que son consejos y pareceres para gobernar nuestra vida y estados; sirviéndome del mediocre para las conversaciones jocosas de graves cortesanos, exercitando el ínfimo para las pláticas risueñas de donosos y truhanes, que por secretos y públicos lugares de seńores, alivian de las pesadumbres de los negocios y gravedades» $(470-471)$.

13. Además, indicó que «los modelos caballerescos y corteses abundan en los entretenimientos de los nobles, e incluso las conversaciones más domésticas y cotidianas se construyen alrededor de conceptos y juegos de palabras bastante alambicados» (Ravasini: 81).

14. En este sentido hay que recordar el estudio de Marín Pina, que demostró que las cartas de amor en los libros de caballerías se convirtieron en modelo para el género epistolar. Como señaló Baranda Leturio (57), en los preliminares de Valerián de Hungría se lee un poema en el que se indica cómo en el libro: «Veréis la pintura d'un buen cortesano / y las calidades que en él se requieren» (Clemente: 7). Y, por supuesto, el conocido ejemplo en la tradición francesa, estudiado por Place, sobre el uso del Trésor d'Amadis como manual de cortesanía verbal; seguramente fue un fenómeno europeo, véase también Byles.

15. Río Nogueras en su estudio sobre el cambio del caballero medieval al cortesano renacentista analizó la importancia de la cortesanía verbal en Amadis de Gaula, donde, aunque se encontraban aún ciertos «resabios de un pensamiento atávico que entra en abierto conflicto con la nueva imagen, más acorde con los tiempos, que del caballero se está forjando» (1993: 73), se asume fundamentalmente la imagen del caballero refinado. Por su parte, Baranda Leturio 
En el presente estudio me centraré en el ciclo de Belianís de Grecia de Jerónimo Fernández ${ }^{16}$. No es mi intención analizar todas y cada una de las intervenciones de los personajes y tampoco pretendo realizar un estudio lingüístico desde los presupuestos de la cortesía verbal ${ }^{17}$. Me centraré en determinar las directrices fundamentales (no en las estructuras morfosintácticas con que se realizan) de la cortesanía en lo que a la expresión verbal se refiere. Esa cortesanía se apoya en el comedimiento y la mesura propias de quien es capaz de controlar sus propias pasiones, lo que no es, además, sino la capacidad de esconderlas, de ocultarlas, de mostrar en público solo una elegante máscara; todo lo cual deriva de la courtoisie medieval entendida como rasgo privativo de la nobleza; no en vano "cortesanía» se opone a "villanía» ${ }^{18}$. Por ello no es de extrańar que se adopte el lenguaje de la sumisión mediante el uso de términos vinculados con el feudalismo (de igual manera que sucede en el amor cortés, que no es sino una parcela de la cortesía). Ese lenguaje de la sumisión conlleva la asunción (fingida) del papel de vasallo, mostrándose humilde, obediente y presentándose uno mismo como un ser inferior al interlocutor. Se trata, como he dicho, de una mascarada, de una convención social que pretende justamente lo contrario: demostrar la propia crianza noble. El análisis de las intervenciones dialogales a la luz de la cortesanía nos ayudará a comprender los matices de las reacciones y actitudes de estos personajes y comprobar qué esconden esas formas de expresión; cuando estos no atienden a las reglas de la cortesanía, su realidad queda al descubierto, se evidencia su verdadera psicología; pero, de lo contrario, esa realidad interna queda oculta bajo el ropaje del comportamiento cortesano. Los protagonistas de estas obras no muestran reparos en fingir, disimular o incluso mentir, sin necesidad de acudir ni siquiera a la «verdad ambigua» (Martín Romero 2008a). La supuesta perfección de los héroes queda en entredicho cuando se parte de este hecho, esa perfección moral no es sino una refinada cortesanía que oculta en muchas ocasiones motivaciones con un punto de egoísmo ${ }^{19}$.

analizó la gestualidad y su valor en el código cortesano en tres obras caballerescas, Zifar, Guarino Mesquino y Palmerín de Oliva.

16. Dejo de lado la $V$ parte manuscrita que no se debe a este autor, sino a Pedro Guiral de Verrio.

17. Sobre la cortesía verbal resulta fundamental el trabajo de conjunto de Haverkate, que recoge los presupuestos de Searle, Grice, Leech y Brown y Levinson. Siguiendo estas teorías (y, por tanto, con presupuestos distintos a los de mi estudio), Rígano estudió la cortesía verbal en Amadis de Gaula. En relación a las fórmulas de tratamiento, es imprescindible el estudio de Ly (1981) que no solo estudia la poética de la interlocución en el teatro de Lope de Vega (como indica el título) sino que aporta todo un panorama histórico de las modalidades de interlocución hasta el siglo XVII, al tiempo que ofrece interesantes reflexiones en torno a sus vínculos con la cortesía y con los distintos rangos sociales del hablante y del oyente.

18. Se opone asimismo a "mala crianza», como forma de hablar de quien no ha sido educado en los refinamientos de la corte o de quien no sigue esos refinamientos. También se opone a «descomedimiento» o "desmesura», pero estos términos implican una ruptura de las normas cortesanas, mientras que «villanía» es un gesto anticortesano esperable en quien no es noble.

19. Expuse estas ideas en otro lugar al hablar de Palmerín de Oliva (Martín Romero 2015). 
Esa representación social, este juego teatral convencionalmente aceptado es lo que se proponía también para el cortesano; Alonso Núñez de Castro ofrece un testimonio de esto en su citado Solo Madrid es corte, cuando explicaba que el que se mostraba más servil, más solícito, esto es, más cortesano, era el que ganaba más respeto: «Necio es quien no sabe que el ser un hombre honrado está en hacer la honra, no en recibirla; y la razón no es dificultosa, porque más honra es recibir agradecimiento por el beneficio que hize que no retornar gracias por el que yo recibí, pues el que se adelanta en la cortesía le hace deudor suyo al otro, y él queda por acreedor de su respeto; luego mejora partido el más cortés» (fol. 59r).

Se trata de mecanismos retóricos que sirven a esa mascarada social, a ese fingimiento necesario para la vida en la corte -que no ha de tomarse (casi) nunca en sentido literal- y que encontramos en los refinados caballeros y damas de la literatura caballeresca.

\section{LA CORTESANÍA VERBAL EN BELIANÍS DE GRECIA}

\section{El lenguaje de la sumisión}

En los libros de caballerías, el lenguaje de la sumisión se evidencia en esa dramatización social que implica la asunción del papel de siervo por parte de quien no lo es; de ahí la tendencia del hablante a situarse en un plano inferior al de su interlocutor; esto conlleva, entre otras cosas, el menosprecio de los méritos propios, como en este ejemplo en el que Belianís accede a un don en blanco que le solicita la princesa Imperia: «Mi señora -dixo el príncipe-, qualquiera cosa que por vos me sea mandado, soy obligado hazer hasta la muerte como vno de vuestros seruidores y vassallos, que tal desseo he tenido continuamente, aunque no sé yo qué es, en lo que vna tal persona de tanto estado como vos, se pueda seruir de vn pobre como hombre como yo» (Fernández 1997: II, 119). Obsérvese que se presenta como uno de sus vasallos (no como su servidor amoroso); sigue una evidente hipérbole de sumisión -se muestra dispuesto y obligado a obedecerla «hasta la muerte»- y continúa con una infravaloración de sus propios méritos (lo que lo sitúa de nuevo por debajo de la dama). Aunque coincide con los rasgos de cortesanía que se han señalado, lo cierto es que en esta ocasión el héroe oculta su alto estado y finge con el propósito de no ser identificado, de manera que no es solo cortesanía, sino engaño. No hay que olvidar que en ocasiones se utiliza el lenguaje de la sumisión no tanto como ceremonia cortesana sino como intento de encubrir la propia identidad, en aquellas ocasiones en las que el héroe, que no quiere ser descubierto, se presenta como un caballero desconocido y de poca valía; esto sucede, por ejemplo, en una ocasión en que Belianís -ocultando su identidad-

Sobre la insinceridad en los tratados de esa época, Laspalas. Sobre la importancia del disimulo en el ámbito cortesano, Snyder: 68-105. 
se ofrece humildemente como paladín en un desafío («aunque para la batalla presente yo no sea tal qual la razón lo demanda», Fernández 2013: III, 365); también lo vemos cuando en territorio infiel habla de sí mismo como «vn pobre hombre» (Fernández 1997: II, 124). En definitiva, el lenguaje de la sumisión no siempre se utiliza de la misma forma y con los mismos objetivos, por lo que hay que valorar en cada ocasión el uso concreto de este tipo de expresión ${ }^{20}$.

Vinculado con ese menosprecio de uno mismo, se da el rechazo del elogio, como en los siguientes ejemplos: «Yo beso vuestras manos, mi señor -respondió la princesa-, por las palabras con que lo que en mi falta auéys querido suplir» (Fernández 1997: I, 363); o en esta otra ocasión, en la que la hermosa Policena responde de esta forma a los elogios que recibe por su belleza: «No sé, excelente princesa -dixo Policena-, qué es la causa que la vuestra merced tanto quiere encarecer mi pequeña hermosura saluo si es para que conoscida la grandeza de la vuestra, que sobre todo el vniversal redondez tenéys, quede en aquel estado de que es merescedora» (Fernández 1997: II, 39). Se ha de notar la habilidad retórica de convertir un elogio en otro, todavía mayor, dirigido al interlocutor.

No obstante, ese rechazo a las alabanzas no siempre implica lo mismo. Así, a veces oculta otro tipo de emociones: cuando Belianís pide a Florisbella que le permita luchar por su belleza -a la que alaba como «el estremo de la hermosura y bondad, sobre todas las nacidas merescistes alcançar» (Fernández 1997: II, 34)-, la dama oculta su indignación (pues piensa que su honra está siendo menoscabada) y rechaza esas palabras: «No sé, señor cauallero, qué es la causa que más a mí que a otra de las presentes pedís essa licencia, pues ellas con más razón os la podían dar juntamente con el fauor que de ser mayor su hermosura se os participara en la batalla» (Belianis II: 34). Florisbella niega ser la más hermosa de las presentes, como manera de establecer distancias con el caballero ${ }^{21}$. La respuesta cortesana no se corresponde con su deseo, pues «quisiérale responder ásperamente» (Belianis II: 34), pero mantiene la compostura cortesana ${ }^{22}$.

También los caballeros rechazan elogios, como Arsileo, que, cuando las damas le piden que acompañe en la batalla a Belianís para infundirle valor, responde: «Aunque de mi presencia ningún esfuerço a tal cauallero seguírsele pueda, pero por cumplir vuestro mandamiento y lo que a este cauallero se le deue, yo soy contento» (Fernández 1997: II, 35). Arsileo no acepta la alabanza y se infravalora, con el objetivo de elogiar al otro, al tiempo que se muestra como servicial a los deseos de las damas. Su humildad y su obediencia demuestran su carácter noble.

20. Otros ejemplos son los siguientes: «no auiendo yo hecho cosa alguna por donde avn andar en compañía de tales caualleros mereciesse» (Fernández I: 289); "siendo yo tan baxo» (Fernández II: 28); "como quiera que de ello yo no soy merescedora» (Fernández II: 124) o cuando el protagonista se refiere a sí mismo como «vn cauallero de tan poco valor» (Fernández II: 52).

21. Aquí también se logra, al tiempo que rechazar un elogio, convertirlo en otro mayor destinado a otras personas, al igual que en el ejemplo anterior se había redirigido al interlocutor.

22. Esa actitud, propia de una gran dama, se va suavizando al contemplar la belleza de las manos del héroe, pues reconoce al caballero de quien se había enamorado. 
La cortesanía también se observa en el campo de batalla, donde reaparece ese lenguaje de la sumisión. Se trata de la misma actitud cortesana que hemos visto en los ejemplos previos, pues, aunque estos caballeros luchen con valor, no es infrecuente que se nieguen a aceptar una victoria, que se presenten como el que lleva lo peor de una batalla, o que acepten con gusto la derrota. De esta forma, Belianís, tras haber vencido a Perianeo en un torneo, le pide disculpas de tal victoria, a lo que este responde: «No ay, señor cauallero, por qué el sucesso presente tanto aya de sentir como vos dezís, pues si algún esfuerço en mí auía hera como vuestro para restituýrosle como tal quando vos quisiessedes y conforme a esto dároslo agora, no ay por qué quedar agrauiado, saluo contento por me auer dexado gozar dél hasta este punto». (Fernández 1997: II, 33-34). El vencido Perianeo devuelve el elogio que Belianís acaba de dedicarle -mecanismo que hemos visto en ejemplos anteriores- afirmando que tuvo ese valor solo para poder devolvérselo. El cruce de palabras implica un saber estar que oculta los verdaderos sentimientos y que coincide con las normas de comportamiento que Núñez de Castro propugnaba en el fragmento citado anteriormente.

Perianeo vuelve a dar muestras de su cortesanía en otra situación similar, cuando una dama le pide que abandone un combate para acompañarla; el caballero accede e incluso afirma que con ello recibe una gran merced tanto por la compañía de la dama como por el hecho de poder abandonar una lucha en la que su derrota era segura: «Sublimada señora -respondió Perianeo-, tan grande es la merced que recibo en saber que por vuestra voluntad se me permite acompańaros como en quitarme la batalla de qualquiera de estos esforçados caualleros, donde no menos que la vida se auenturaua y pues a ellos no solo por su esfuerço, mas por vuestra parte se les deue vitor[i]a, yo les suplico la reciban» (Fernández 1997: II, 183).

Este caballero pide a sus adversarios que acepten la victoria, un gesto cortesano que lo sitúa, en tanto que más humilde, por encima de estos; uno de ellos -Arsileo- responde: «A vos, estremado cauallero y el más esforçado de los que he visto, se deuen todas las vitorias, pues no sólo con el esfuerço las ganáys, pero aún con vuestra muy sublimada criança las acrecentáys conseruándolas en aquel estado de que son merecedoras» (Fernández 1997: II, 183). Son muy significativas estas palabras, pues recuerdan que el estatus social se revela no solo por el valor guerrero, sino también por la «criança» (esto es, la educación, la sofisticación propia del noble). Aristeo reconoce que las palabras de Perianeo son muestra de su cortesanía y esta, a su vez, de su nobleza.

En otro caso un caballero -Clarineo de España- agradece no haber continuado con el combate, ya que da por sentado que iba a ser vencido; además, afirma que esa derrota era segura por el valor que demostraba su contrario no solo en su habilidad guerrera sino también en sus palabras: «Yo os lo tengo en merced, señor cauallero -respondió Clarineo de España-, y tengo por muy dichoso acaescimiento el mío en no auer venido a la batalla de las espadas con tal cauallero como vos, pues hera tan cierto ser yo vencido quanto tales palabras dello pueden dar testimonio» (Fernández 1997: I, 278). 
Encontramos otro caso de cortesanía en la batalla en este pasaje en el que Belianís acepta dejar de luchar a petición de una dama («Señora donzella, son tan grandes las mercedes que yo recibo en quitarme d'esta batalla que no sé con qué a la señora que os embía lo pueda servir», Fernández 2013: III, 325). Como puede observarse, no solo consiente en dejar de combatir, sino que considera que así recibe un favor -ha de entenderse por llevar lo peor de la batalla - y lo encarece tanto como para no ser capaz de imaginar cómo podrá agradecérselo. No es que Belianís piense realmente eso, sino que adopta esa postura humilde que no es sino una envoltura cortesana. La dama le ha enviado una joya que previamente le había arrebatado mientras dormía, y el caballero, al recuperarla (y, por cierto, saberse identificado), habla de esta joya en los siguientes términos: «estuvo guardada para tan gran subcesso como es quitarme de tan mortal batalla» (Fernández 2013: III, 325)23.

La cortesanía en el ámbito de los combates judiciales brilla aún más. Eso sucede por ejemplo cuando en un determinado momento Belianís es avisado por su contendiente de una regla del desafío cuya ignorancia lo hubiera perjudicado. El héroe es consciente de la nobleza de su adversario y afirma que esas palabras de aviso le causan más temor, en tanto que muestran la perfección de quien las ha pronunciado: «Estremado cavallero, mayor temor me han puesto los tan abentajados cumplimientos vuestros y soberana criança que no la pavosora muerte, aunque mis ojos la vieran representada, pues con ella se muestra el esfuerço vuestro ser más cumplido de crecidas obras que de sobradas palabras» (Fernández 2013: III, 230).

Continúa afirmando que en la «contienda de la razón» (Fernández 2013: III, 230) ha sido derrotado (recordemos las palabras de Solo Madrid es corte: «el que se adelanta en la cortesía le hace deudor suyo al otro») y que, aunque se ve obligado a la batalla, es mayor la lucha interna - por tener que enfrentarse a tan noble adversario- que el combate real que lo espera: «y, pues en la batalla de la razón por vos he sido vencido, no lo quiero ser en lo demás por mi propria mano. Por tanto, si sin vuestra batalla el fin de mi demanda alcançar no se puede, cúmplase como fuere possible, con que vos certifico que la recibo sin comparación mayor de mí mismo en averla con vos» (Fernández 2013: III, 230).

Todo esto se vincula con el rechazo a la soberbia que se propugnaba en diversos tratados. Antonio de Guevara indicaba en su capítulo XIII «que los privados de los príncipes se deven guardar que no sean soberbios» (fol. 99r). Castiglione afirmaba que "guardarse ha nuestro Cortesano de presumir locamente» (157) - por supuesto, decía que no ha de ser «fanfarrón» (157)- e indicaba la forma correcta de elogiarse uno mismo: «Y si quisiere tocar algo en loor suyo, hágalo disimuladamente, como acaso, sin detenerse en ello» (1984: 149).

23. Concluye incidiendo en la gratitud de que se ha hecho acreedora la dama por tan gran favor: «nuevo conoscimiento será menester para servir tan grandes mercedes, que no dexaré de la besar las manos antes que me parta» (Fernández 2013: III, 325). 
En los libros de caballerías se opone soberbia de palabras al valor de las obras, como cuando el héroe indica a uno de sus adversarios que acababa de poner su valor por encima del de otros caballeros: «De todo te estimas tanto -dixo don Belianís- que creo que las obras no serán nada» (Fernández 2013: III, 345).

Otro rasgo de cortesanía es la infravaloración de la ayuda que el hablante ha prestado, así como la expresión de obligación y gratitud extremas al oyente; en la siguiente cita el héroe recompensa -con formas cortesanas-a un caballero con un señorío: en primer lugar, alaba en extremo su valor y afirma que es imposible encontrar una recompensa que esté a su altura («Esforçado cauallero, si lo mucho que vuestro esfuerço y persona merece se os vuiesse de galardonar, no bastaría todo este reyno que a vuestra causa se a ganado para ello», Fernández 1997: I, 288); e inmediatamente pide que no mire la escasa valía de esta recompensa -se trata de una hipérbole, pues se trata de un señorío-, sino la voluntad (enorme, ha de entenderse) con que se ofrece ("pero no mirando a la poquedad del agradecimiento sino a la voluntad con que se os da, recebid por vuestro el señorío del conde Gariano», Fernández 1997: I, 288); todo esto, por cierto, recuerda al tópico que se encuentra en tantas dedicatorias de la época, no en vano en estas se asume el papel de servidor ante una persona (el dedicatario) de mayor estatus social, siguiendo las pautas del habla cortesana.

Asimismo, cuando la duquesa Ysperia acepta a Belianís como su defensor, el héroe rechaza cortésmente su gratitud afirmando que es él quien recibe el favor: «Señora duquesa -respondió el príncipe-, teniendo vos essa de vuestra parte poco tenéys que me agradecer cosa que por vos haga, antes yo rescibo crecidas mercedes en que me la queráys otorgar» (Fernández 1997: II, 124125).

Eso mismo sucede cuando el mismísimo rey de Inglaterra va a visitar al desconocido Caballero del Liocornio (que en realidad es Belianís, que oculta su identidad); este agradece la merced ${ }^{24}$; a esto, el monarca responde rechazando ese elogio y alabando a su interlocutor: «Dexémonos d'esso -dixo el rey-, que no puede aver cumplimiento en ningún príncipe que de mayor no seáys merecedor, que ya no creo me vendrá día de mayor plazer que este, por me hallar en vuestra compañía» (Fernández 2013: III, 302).

En otra ocasión, un caballero, el duque Armindos, presenta poder ayudar a Perianeo, príncipe de Persia, como una suerte y no como un favor ofrecido, pues niega que el príncipe necesite su ayuda y, de hecho, afirma que le está arrebatando la gloria de un éxito seguro: «Mi señor, no pensé que jamás mi ventura me hiziera merecedor de poderos hazer algún servicio, porque con

24. El agradecimiento expresado de forma hiperbólica por parte del héroe se vincula, siguiendo el lenguaje de la sumisión, con la infravaloración de los propios méritos: «No sin causa, esclarescido señor, soys tenido por el más noble príncipe del mundo, pues tan gran merced havéys hecho a un cavallero andante y de tan poca nombradía como yo soy» (Fernández 2013: III, 302). 
ser en esta batalla por vuestra parte antes será quitaros la fama que con tan cierta victoria por vos solo se esperaba» (Fernández 2013: III, 352-353). A estas palabras de alabanza, Perianeo responde a su vez elogiando el valor del duque: "vuestro valor para ser conoscido tiene pequeña necessidad de nuevas experiencias» (Fernández 2013: III, 352-353), una alabanza cortesana que implica, al mismo tiempo, un rechazo del elogio que previamente había recibido.

El agradecimiento hiperbólico también forma parte del habla cortesana. Belianís agradece a princesas y damas que lo visitan su amabilidad con unas palabras que, si por una parte muestran su agradecimiento sin límites, por otra también reflejan su humildad:

Mis señoras -respondió don Belianís-, son tan crecidas las mercedes que por tan altas princesas se hazen a un cauallero de tan poco valor, que ni tengo palabras para las agradecer ni puede auer obras con que las seruir, solamente digo que pues mi merecimiento no se puede extender a tanto tomen lo que puede que es mi voluntad y desseo, con la qual perpetuamente estaré debaxo de la obligación de su seruicio hasta la muerte sin poder jamás della salir. (Fernández 1997: II, 52) ${ }^{25}$

Obsérvese también la manera como, en otra ocasión, Lucidaner se muestra agradecido a una dama. El caballero presenta un favor que le han pedido como una merced que recibe; se trata de que Florisbella, la protagonista, había solicitado al caballero que dejara a Policena -la dama a la que este acompañabaque se quedara con ella; Lucidaner entonces responde agradeciendo que la princesa requiera algo de él:

Hermosa señora, diréys a mi señora, la princesa Florisbella, que es tan grande la merced que del fauor presente recibo que, como no merescedor dél, me haze creher que es para del todo subirme en lo más alto del estado humano, para que puesto en la más alta cumbre por su mano, como ingrato no reconociendo la gran merced recibida sea dél abaxo derrocado por me hallar al presente contrario de su seruicio y en lo demás que toca a mi señora, pues mi coraçón por el suyo se gouierna, no ay más que dezir que obedescer conforme a como ella fuera seruida. (Fernández 1997: II, 37)

Los juegos verbales, el silogismo y el ingenio (por no hablar de la hipérbole de su humildad) revelan su cortesanía; sus palabras recogen el lenguaje de la sumisión: la obediencia sin límites, la consideración de uno mismo como inferior al interlocutor, el agradecimiento desmesurado, la concesión de una petición vista como un favor recibido, a lo que se ańade una vuelta de tuerca: el pensamiento de que ese enorme favor recibido no sea sino una forma de castigarlo por no reconocer esa inmensa merced.

En definitiva, la cortesanía verbal se evidencia en una serie de directrices propias de lo que he dado en llamar lenguaje de la sumisión: 1) el menosprecio de los méritos propios, 2) el rechazo del elogio -en lo que se incluye 2.2.) el

25. Resulta difícil no recordar los conocidos versos de Garcilaso en su Tercera Égloga a la dedicataria, María, que también son una muestra de este tipo de cortesanía. 
negarse a aceptar una victoria o 2.3.) presentarse como el que lleva lo peor de una batalla-, 3) la infravaloración de la ayuda prestada y 4) la expresión de obligación y gratitud extremas al oyente.

Como se ha podido comprobar en estos ejemplos, se suele expresar en el más alto grado tanto el menosprecio de uno mismo (o sus acciones), como los elogios del interlocutor (o de la merced que éste hace al hablante). Por tanto, hipérbole y lenguaje de la sumisión están unidos en la práctica de la conversación cortesana.

\section{La mentira diplomática}

La cortesanía fuerza en ocasiones a negar la verdad mediante una agradable cobertura de elogio. Esto sucede, por ejemplo, en una ocasión en que Florisbella, prisionera mediante un encantamiento, afirma no querer ser liberada para seguir gozando de la compañía de nobles damas que allí se encuentran. Efectivamente, cuando una de estas (nada menos que Juno) le cuenta que unos caballeros han venido a liberarlas, la princesa encerrada en ese castillo afirma: "Vamos - dixo la princesa-, que desseo ver alguna cosa, aunque no querría perder por todo el mundo tal compañía» (Fernández 2013: III, 356). Inmediatamente antes se había comentado que la princesa lamentaba estar ausente de su familia y, que precisamente ese día «más ocupada en sus lamentaciones estava» (Fernández 2013: III, 356). Por tanto, la concesiva mediante la cual afirma no querer perder la compañía de las damas «por todo el mundo" no es sino una mentira cortesana vinculada con el refinamiento de costumbres esperable en todo noble.

Algo parecido sucede cuando Juno entrega a Florisbella un espejo en el que puede observar a su amado Belianís; ella, ante esta visión, siente recuperar sus fuerzas y afirma: "Agora, soberana señora, tengo entendido que nos queréys detener aquí mucho tiempo, pues tal entretenimiento avéys dado a mi vida» (Fernández 2013: III, 245), pero continúa enfatizando lo agradable de su compañía diciendo que todo el tiempo que estén juntas le parecerá poco: «aunque, en la dulce conversación presente, qualquier tiempo para le goçar es corto» (Fernández 2013: III, 245). Florisbella es capaz de callar sus sentimientos hacia Belianís no solo porque su honra quedaría menoscabada, sino porque afirmar que quiere salir del encierro implicaría no valorar lo suficiente la compañía de tan excelentes personas. Como princesa y acostumbrada a los comportamientos de palacio, ha de demostrar su carácter cortesano alabando de forma elegante a esas damas. La diplomacia cortés implica no mostrar de forma descarnada sus verdaderos sentimientos cuando estos pueden herir o molestar al otro.

En otra ocasión, volvemos a encontrar la mentira cortesana cuando la emperatriz se reencuentra con las princesas y damas una vez que han sido liberadas; aquella afirma entonces que, de haber sido raptada con ellas, hubiera estado "contenta» de ser prisionera, una diplomática falsedad o una cortés 
mentira (solo en tanto que falsedad, pues se da por sentado que el interlocutor lo interpretará de forma correcta). A esto responde otra dama, Imperia, en un tono igualmente cortesano, afirmando que, si hubiera sido así, no hubieran estado tan deseosas de salir:

-¡Ay de mí, queridas señoras - dezía la emperatriz-, y quán cruel fue aquel traydor que ansí me dexó, sola, privada de vuestra tan sabrosa combersación, que ya si a mí también me llevara quedara contenta!

-Mi señora -respondió Imperia-, si esso fuera, no desseáramos salir tan presto, que ha sido la principal causa de nuestra libertad, con la priessa que avemos dado a los que nos guardavan. (Fernández 2013: III, 402)

Tampoco Imperia debe ser aquí interpretada de forma literal, no está diciendo la verdad, está elogiando mediante la mentira cortesana a la emperatriz, cuya compañía se presenta tan agradable que hubiera hecho feliz incluso el cautiverio que han sufrido ${ }^{26}$.

En definitiva, la cortesanía implica no solo ser capaz de envolver la verdad con ropajes cortesanos, sino también de disfrazar la mentira con el fin de agradar al interlocutor, que sabe interpretar esas falsedades como amabilidad.

\section{Elogio y requiebros amorosos}

Como es de esperar, el elogio aparece relacionado con el requiebro amoroso. Quizá este haya sido uno de los aspectos más comentados al vincularse con el tema del amor. Aunque no siempre en los libros de caballerías se trata de amor courtois tal como lo definió Lewis (1-43), es cierto que al menos ciertos rasgos de la cortesía medieval suelen estar presentes, si bien en no pocas ocasiones mezclados con otras filosofías del amor (Martín Romero 2008b). También en la realidad histórica, las normas corteses seguían propugnándose en el siglo XVI, como demuestra el Aviso de privados y doctrina de cortesanos de Antonio de Guevara: «El que se ofrece a servir a una dama, ofrécese a guardar una religión muy estrecha, porque ha de estar cabe ella de rodillas, delante de ella en pie, tener siempre quitada la gorra, no hablar sin que ella lo mande, si le pidiere algo, dárselo, si le mostrare mal gesto, sufrírselo, por manera que en ninguna cosa se ha de ocupar ni a su hacienda emplear si no es en a su dama servir» (fol. 75).

Aun cuando la idealización del sentimiento amoroso sea norma en estos textos, no toda relación erótica ha de entenderse así. En los libros de caballerías los caballeros y damas se dan a los placeres de la carne con cierta libertad (cada

26. No se trata realmente de mentir en tanto que no hay voluntad de engañar: el oyente, como he indicado, sabe interpretar el mensaje de forma adecuada. De igual manera hay que entender las palabras del soldán de Babilonia ante una petición del príncipe Perianeo: «No auía, soberano príncipe, necessidad de licencia para qualquiera cosa que en mi corte vos quisiérades hazer pues en ella como yo mismo podéys mandar» (Fernández 1997: II, 19). Se trata no tanto de una mentira como de una hipérbole mediante la cual el Soldán revela su magnificencia. 
personaje a su manera). Incluso cuando la relación es puramente sexual, el lenguaje utilizado puede derivar del amor cortés. Por ello, se ha de matizar hasta qué punto estos caballeros siguen las normas del fin' amors o simplemente la retórica del galanteo. De igual manera que sabemos que Calisto desea físicamente a Melibea y que sus palabras corteses esconden lujuria, en los libros de caballerías los personajes saben utilizar, como Calisto, las palabras para conseguir sus objetivos sexuales. En Belianis de Grecia, una dama, Matarrosa, lo afirma claramente: «todos los caualleros hazéys esas muestras aunque no las tengáys en el coraçón» (Fernández 2013: II, 53).

Además, también se da el elogio a la dama y el galanteo cortesano como juego o fingimiento aceptado por ambas partes, como representación sin implicaciones amorosas de ningún tipo, algo que ya fue analizado en Amadis de Gaula por Javier Roberto González, que habló de actitudes pseudocorteses para referirse a los requiebros amorosos «a modo de juego y gracia» entre Amadís y las nińas Leonoreta y Leonorina $(73)^{27}$. Son pseudocorteses a la luz del amor cortés - pues no hay enamoramiento real-, pero se adecuan plenamente a la mascarada cortesana ${ }^{28}$.

En la expresión del amor no es infrecuente que encontremos juegos de palabras procedentes de la tradición cancioneril cuando un caballero elogia a una dama con la intención de declararle sus sentimientos. Así, Clarineo, hermano de Belianís, no duda en hablar a Roseliana de esta forma en cuanto la ve: «Mi señora, suplico a vuestra grandeza seáys servida de que vuestra soberana vista no aya sido para dexarnos en las tinieblas que vuestra ausencia nos podría causar, tanto mayor quanto los claros rayos de vuestra hermosura a todos los mortales exceden, con la ventaja que en vos tan clara se parece» (Fernández 2013: III, 254). El caballero juega con los términos "vista» y «tinieblas», vinculando el primer término no solo a la acción de ver sino también a la presencia de la dama, cuya hermosura se identifica con «claros rayos», de manera que su ausencia se convierte en «tinieblas». Es más, continúa con la misma intención y con las mismas herramientas retóricas; así, habla del «peligro» no sólo para referirse a los combates y pruebas que ha de pasar para liberar a la dama, sino a las heridas amorosas por haberla visto; por ello habla,

27. Este investigador sustenta bien su clasificación en actitudes «corteses», «paracorteses», «anticorteses», «pseudocorteses» y «ultracorteses»; no obstante, no hay que olvidar que habla de esas actitudes en relación al amor cortés, no en tanto al comportamiento cortesano (que incluiría no sólo la actitud «cortés», sino también la "paracortés», "pseudocortés» y «ultracortés», en tanto que la cortesía implica ese carácter de juego, de representación).

28. Coincido con Baranda Leturio, quien, al hablar de la gestualidad cortesana, afirmó que «en los libros hispánicos estos gestos se comprenden dentro de un sistema bien organizado y que debía ser reconocido por el lector, el cual, interpretándolo dentro del código, podía atribuir a cada gesto un significado preciso que le sirviera para situar a cada personaje en relación con los demás y con el mundo en que se desenvuelve» (67). Las palabras de esta investigadora en relación con los gestos se pueden aplicar a las palabras cortesanas. Es más, en mi opinión el lector contemporáneo era capaz no solo de interpretar esos gestos para conocer el rango social de cada personaje, sino también para determinar el grado de veracidad que se había de dar a esas palabras, de manera similar a como hoy día somos capaces de interpretar el sentido de expresiones de educación vacías de significado (que en ningún caso tomamos al pie de la letra). 
en estilo abiertamente cancioneril, de que ese riesgo promete «muerte tan gloriosa»: "Excelente señora - dixo don Clarineo-, vuestra sobrada hermosura da testimonio del peligro ser mayor que lo que se encarece, aunque promete la muerte tan gloriosa que por esta parte todos la devíamos procurar» (Fernández 2013: III: 255). Jugando con las palabras, pregunta el motivo de su prisión, reconociendo que hubiera sido mejor para él que estuviera más encerrada aún porque así no la habría visto y no sufriría por su amor: «Por tanto, suplíco’s tengáys por bien de hazernos savidores de la causa de tan grande encerramiento como aquí parece; aunque para mí no fuera malo ser mayor, pues quedara libre de tan cruel erida y tan incurable como al presente he recebido» (Fernández 2013: III: 255).

Como se ha visto, la hipérbole juega un papel fundamental en la expresión cortesana. Por ello, en lo relativo a los elogios a damas, no se escatiman las exageraciones; obsérvese cómo Belianís se justifica ante princesas y damas por un momentáneo desvanecimiento ante la visión de su amada Florisbella; la justificación conlleva un elogio a todas ellas:

$\mathrm{vu}[\mathrm{e}]$ stras presencias aun a los inmortales dioses parecen no ser comunicables y me parece no ser inconueniente que dexadas sus deydades en la semejante gloria que la vuestra vista se recrece conuertirse quisiessen y esto más que otra cosa es de creer causaría mi alteración porque en lo demás, si a vuestras excelentes personas algún enojo pensara auer causado, no hera justo que con menor castigo que con la vida se satisfiziesse, pues aquélla en complazer y seruir a las semejantes es gloria empleársela. (Fernández 1997: II, 51)

Lo que se deriva de su razonamiento es lo siguiente: si incluso los dioses no están a salvo de reaccionar ante tanta hermosura, tanto menos él. Concluye su parlamento ofreciendo su servicio a las damas tras haber afirmado-de nuevo una hipérbole- que se consideraría digno de muerte si les hubiera causado la menor molestia. Se utiliza la justificación para un elogio exagerado a las damas y ofrecerles su servicio e, incluso, su vida. La elegancia de su estilo y el uso retórico demuestra un ingenio no demasiado alejado de los juegos conceptuales de la poesía cancioneril en la que ese ingenio es visto como signo de cortesanía.

Pondré tan solo otro ejemplo de esto, procedente de la primera parte de Belianis de Grecia; se trata de cuando un caballero -Arsileo- aprovecha un elogio a Florisbella para alabar a otra dama -Matarrosa-, cuya vista lo ha embelesado (aunque lo atribuye a Florisbella, jerárquicamente superior):

Si la turbación de la vista presente, alta y poderosa princesa de Babilonia, basta ha poner en cuydado a los soberanos dioses quanto más a los mortales para querer ver en lo que ellos todo su poder mostraron, por lo qual por señora del vniverso al presente os quisieron dexar dándoos el mundo por destierro, pues sola la bienauenturança de que ellos gozan es la que a la virtud de vuestra persona satisfazer puede (Fernández 1997: I, 362)

La hipérbole se apoya en la idea de que los dioses (se encuentran en territorio pagano) la han desterrado al mundo, pero la han hecho "señora del vniverso», y justifica que lo es porque únicamente la «bienaventurança» divina puede 
alcanzar los méritos de esta dama. Pero, como he indicado, la turbación ha venido causada por otra, Matarrosa; forzado a elogiar a Florisbella antes que a nadie, aprovecha la circunstancia cortesana para construir (a partir de este) otro elogio dirigido a la dama de la que se ha enamorado: «avnque en el presente destierro no poco tenéys que les agradecer pues tal compañía como la de la princesa presente os quisieron dar, cuya gracia y hermosura a sola de la vuestra recibe comparación y pagar la deuda que como vassallo os deue» (Fernández 1997: I, 362-363).

Por tanto, utiliza un elogio inicial que desemboca en otro al comentar que Florisbella debe estar agradecida a los dioses por haberle permitido estar en compañía de esta otra doncella. De esa manera, rehúye el elogio directo y el peligro de que su requiebro amoroso resulte demasiado evidente. Ingenio, retórica y cortesanía van de la mano en estas intervenciones.

\section{La negativa cortés}

Otro punto importante de la cortesía es la forma adecuada de negarse. La negativa cortés implica diversas herramientas retóricas para amortiguar la reacción. Un caso evidente es la forma como Belianís rechaza amablemente el acercamiento amoroso de una princesa, Claristea, o mejor dicho, la propuesta que esta le hace llegar por medio de una de sus damas, Lindorena; esta doncella tantea la voluntad del héroe en relación a su señora («la princesa, mi señora, con ninguno casaría de mejor voluntad» (Fernández 2013: III, 235), a lo que Belianís responde: «-Tal ventura como essa, mi señora -dixo don Belianís-, no está guardada para cavallero de tan poco merecimiento, que sería locura pensarla» (Fernández 2013: III, 235). De esa manera, oculta sus sentimientos, que no es tanto considerarse indigno de tal propuesta sino evitar las complicaciones que le acarrearían (tanto más cuanto que ya está enamorado de otra); de hecho, se indica expresamente que "pesole en el alma» (Fernández 2013: III, 235). Las palabras de Belianís no expresan su verdadera opinión al respecto porque la cortesanía le impide ser más claro, pero no lo necesita, porque, tanto en el universo ficticio de los libros de caballerías, como en la realidad de sus lectores coetáneos se entendía perfectamente que sus palabras no eran sino una excusa cortés para un rechazo rotundo.

En otra ocasión, otro de los personajes, don Clarineo, se niega a detenerse para ser curado por unas doncellas: «Mis señoras -respondió el príncipe-, yo recibiera soberana merced, más que otro ningún cavallero, en poder obedecer vuestro mandamiento. Mas tengo tanto que hazer que me sería mal contado si en parte alguna me detuviesse hasta aver acabado esta aventura; la qual, si con la vida escapo, yo bolveré a cumplir vuestro mandamiento» (Fernández 2013: III, 260). Aquí la negativa viene precedida por la afirmación de su deseo de obedecer y de que consideraría hacerlo una «soberana merced». Esas palabras previas desembocan en una oración adversativa que contradice lo anterior, al no acceder a detenerse. 
Y todo ello porque negarse es un gesto abiertamente anticortesano; es por eso por lo que se han de utilizar todos los recursos retóricos necesarios para suavizarlo. Esto resulta especialmente evidente si se compara con aquellos momentos en los que se abandona, si no la cortesía, sí el juego cortesano de autopresentación como siervo; eso sucede cuando en una ocasión Claristea pide a Belianís que no luche, pues está herido, a lo que él se niega; no lo hace de forma desmesurada, pero rompe con la ficción de la infinita humildad y, además, abandona la sofisticación retórica en el hablar: «-Señora-respondió don Belianís-, esta ventura se defiende a mi causa, y no puedo dexar de tomar las armas, aunque creo no serán necessarias. Yo quisiera cumplir vuestro mandado, mas va mi honra en esto» (Fernández 2013: III, 239). Aquí el estilo es directo, claro y sin juegos de palabras. La justificación de la negativa es la defensa de la propia honra, de manera que no hay lugar para mantener la cobertura de servidumbre: no puede obedecer y así se lo hace saber. Quizá se pueda intuir una cierta molestia con la dama, cuyos acercamientos amorosos lo torturaban, y una manera de dejar claro que no era su caballero. Mayor cortesanía se encuentra en sus contendientes, que lamentan una lucha en la que el héroe participa herido: «Bien veo, S[eñor] cavallero, la sin razón que se os haze en offreceros nueva batalla; mas, pues vuestro coraçón a todo se estiende, supplíco's perdonéys nuestro mal comedimiento, que todo será al fin para acrecentar vuestra fama, y sea nuestra batalla con las condiciones que an sido las de los cavalleros passados» (Fernández 2013: III, 239).

De hecho, cuando posteriormente Belianís lucha contra Perianeo, que durante esa parte de la obra es su rival amoroso y, por tanto, su peor enemigo, la princesa vuelve a pedirle que abandone la lucha e incide en la necesidad de que acepte su ruego si quiere comportarse de forma cortés: «no es mi voluntad que más guardéys esta aventura. Gran sinraçón me hazéys en menospreciar mi ruego, y nunca de vos perderé esta quexa» (Fernández 2013: III: 241). La respuesta del héroe, furioso ante esta interferencia, resulta claramente alejada del autocontrol cortesano, pues apenas puede dominar su ira: «Mayor es esse agravio, señora, que no el primero. Ya no me podéys hazer tanto bien con que el pesar que tengo no me dure hasta la muerte. Acabad con el cavallero que la dexe, que yo la dexo por el presente tan contra mi voluntad que antes fuera contento de recebir la muerte a sus manos» (Fernández 2013: III, 242). Ante esa respuesta desmesurada, la doncella no responde y solicita también a Perianeo que abandone la lucha. La comparación entre la respuesta de este caballero y la que acabo de analizar por parte de Belianís evidencia la diferencia diametral entre ambas, pues Perianeo responde siguiendo las pautas de la cortesanía: «Excelente señora -dixo Perianeo-, aunque yo tuviera la vida y la batalla ganada, fuera poco perderla por vuestro servicio» (Fernández 2013: III, 242).

Me interesa aquí señalar que las herramientas retóricas son semejantes a las que encontramos en el tratado de Castiglione; cuando Pietro Bembo cuenta una anécdota contra los florentinos, doña Emilia Pía pregunta a miser Bernardo, Cardenal de Santa María in Acuto, por qué acepta esa crítica, y 
este responde: "Yo le perdono esa injuria; porque si él me ha hecho pesar en burlar de los florentines, hame hecho el mayor placer en obedeceros, y lo mismo haré yo siempre que se ofrezca caso para ello» (189) (efectivamente, Bembo había seguido las indicaciones de la dama, que le había pedido que contara una anécdota graciosa). La cortesanía del texto de Castiglione deriva claramente de la cortesía medieval, en tanto que el hombre se sitúa siempre por debajo de la dama, a la que ha de obedecer en cualquier aspecto. Es evidente que en este fragmento de El Cortesano refleja conductas que tienen mucho de pose social y eso mismo es lo que vemos en muchas ocasiones en los libros de caballerías. Si en el texto italiano Bernardo afirma haber obtenido mayor placer recibiendo injuria al ver obedecida a dońa Emilia Pía, Perianeo afirma que perder la vida sería poco en servicio de la dama a la que acaba de conocer. De esta forma, el caballero se muestra como cortesano no solo porque acepte seguir la voluntad de la doncella, sino porque en su respuesta retoma la ficción cortesana, la asunción del papel de súbdito que todo le debe al oyente y lo hace con una hipérbole que no se ha de entender en sentido literal. Frente a esto, Belianís en esta ocasión no logra sujetar sus emociones (el odio que siente ante su contrario) y, aunque acepta igualmente, le reprocha a la dama el "agravio» que eso supone y, por si fuera poco, utiliza una hipérbole que invierte lo cortés: la dama jamás podrá hacerle ningún bien para evitar que el pesar no le dure hasta la muerte. Se trata de la inversión de la infinita gratitud debida y de la incapacidad de corresponder a la magnitud del servicio: frente a esto, Belianís niega la capacidad del receptor -la dama- de realizar un servicio comparable al mal que le ha causado. Los matices expresivos son notables y evidencian más del carácter de los personajes de lo que pudiera pensarse en un primer momento ${ }^{29}$.

Compárese cómo en otra ocasión el héroe se había mostrado más cortesano al negarse a la petición del emperador de abandonar un combate: afirma que lleva lo peor de la batalla (rasgo de humildad propio de la cortesanía), y, que, por tanto, le conviene abandonar la lucha, para inmediatamente ańadir una adversativa en la que rechaza obedecer:

-Poderoso señor, conocida cosa es que lo que el emperador, mi señor, me manda, me estaría a mí mejor que otro alguno, assí por mis heridas como por estorvarme una batalla de tan valeroso príncipe como don Daristeo; y a esta causa y del mandado del emperador yo fuera muy contento se quedara, mas yo tengo prometido de no comer ni salir d'este campo, salvo vencido o vencedor. Por tanto a tal intercessión recibades culpa, con el emperador, en no cumplir vuestros mandamientos, que certifico que no es en mi mano hazer otra cosa. (Fernández 2013: III, 232)

29. Puede sorprender que esta vez Perianeo supere en cortesanía a Belianís, pero la actitud del héroe se entiende en tanto que ha ido sufriendo un desgaste por parte de esta dama, que le ha enviado mensajeras de amor en un momento en que no puede dejar de pensar en su amada Florisbella (raptada y alejada de su lado), que le ha impedido luchar en otra ocasión y que de nuevo vuelve a hacerlo. Resulta lógico que el héroe finalmente estalle. La gradación psicológica es evidente y se revela en la forma como Belianís se dirige a la dama en los diversos momentos. 
Los motivos reales de la negación y la verdadera reacción de Belianís han sido expuestos justamente antes: «Mucho le pesó a don Belianís de lo que el emperador le mandava, cuidando que, si lo tal hiziesse, no cumplía enteramente con su honra» (Fernández 2013: III, 232). Efectivamente, se trata de una batalla entre el héroe y un personaje, Daristeo, que previamente lo había afrentado. El recuerdo de esa afrenta explica la reacción psicológica de Belianís, que respondió «acordándosele de las sobradas palabras de don Dariste[o]» (Fernández 2013: III, 232). A pesar de ello, oculta esa indignación por la afrenta recibida, y envuelve en actitudes cortesanas de humildad y sumisión lo que no es sino desobediencia.

En ocasiones se produce una negativa antes de la petición, lo que demuestra una habilidad retórica notable. Eso sucede cuando Belianís intuye que le pedirán que revele su identidad o que permanezca una noche en una determinada corte; entonces, adelantándose, finge aceptar el don en blanco, cuando en realidad no lo hace. En primer lugar, alude a su obligación de acatar el mandado de la princesa (afirma que la desobediencia implicaría la muerte: «No ay quien pueda resistir -respondió el príncipe- a mandamiento de quien, haziendo lo contrario, no se puede sustentar la vida», Fernández 2013: III, 302). Continúa animando a la dama a que le dé órdenes, pues cumplirá cualquier cosa que le pida («Por esso la vuestra merced me mande, que qualquiera servicio que yo pueda haré muy enteramente», Fernández 2013: III, 302) y es entonces cuando se niega de antemano a las dos cosas que piensa que le rogarán: «solo que dezir mi nombre ni fincar aquí esta noche me sea mandado, que ninguna d'estas dos cosas soy parte para cumplir, aunque quiera; si no, caygo en la mayor falta que nunca cayó cavallero» (Fernández 2013: III, 302). El caballero adopta la pose de súbdito, pero sin llevarlo a efecto. Las palabras están vacías de contenido, en el sentido de que él intuye que se está negando a hacer justamente lo que se le pedirá y, aun así, lo envuelve en una fingida (esto es, cortesana) sumisión de tipo feudal que no le impide negarse de antemano alegando razones de honra.

Por tanto, no se ha de interpretar de forma literal la ceremonia cortés. En otra ocasión el agradecimiento por haber sido apartado de una batalla se produce de forma falaz, pues inmediatamente se niega a hacerlo. Así sucede cuando unos caballeros piden a Lucidaner (que lucha contra Perianeo) que deje el combate ${ }^{30}$. Lucidaner se muestra agradecido, pero concluye rechazando la petición: «Buenos señores, yo vos agradezco la honrra que a mí más que a este cauallero hazéys en me quitar desta batalla, la qual por el presente no se puede dexar sin la fenescer, porque este cauallero busca a otro que yo mucho amo para auer con él batalla, la qual tiene primero que con él encuentre fenescer comigo» (Fernández 1997: II, 101-102). Cuando los caballeros ven que no dejan de luchar, los consideran «más malcriados que corteses» (Fernández

30. Por cierto, que la cortesía va más allá de las palabras. Durante el combate Perianeo se muestra cortés, primero al proporcionarle una espada a su adversario y, luego, al ver que este la rechazaba, abandonando la suya para luchar en igualdad de condiciones «no quiriendo vsar de villanía» (Fernández 1997: II, 102). 
1997: II, 101-102) y entran también en la contienda. Aunque en este caso, la retórica no convence a los interlocutores, lo cierto es que el caballero se expresa de forma impecablemente cortesana.

\section{Las burlas: entre la cortesanía y la descortesía}

Otro de los rasgos en los que se evidencia la cortesanía es la forma como insultar o atacar con palabras elegantes, así como la manera de responder a palabras hirientes. En ocasiones está vinculada con donaires y el humor cortesanos $^{31}$. Esos aspectos lúdicos de la conversación se relacionan en ocasiones con comentarios de Castiglione sobre «los dichos prestos y agudos, y que alguna vez pican [...] y aun parece que no tienen gracia si no muerden algo» $(180)^{32}$.

Belianís se muestra cortesano incluso al ser objeto de burla cuando, tras un infortunio, se dirige a unos torneos en una cabalgadura tan triste que causa risa en una compañía de damas y caballeros que iban «tan bien adereçados que gran sabor dava mirarlos» (Fernández 2013: III, 283). Una de las damas lo increpa: «Señor cavallero, ¿por qué no havéys duelo de vuestro cavallo, que con razón se podrá quexar de vos?» (Fernández 2013: III, 284), a lo que el héroe responde alejando la crítica y no cayendo en el insulto: «Señora -dixo don Belianís-, quando de mi cavallo la vuestra merced muestra dolerse, con razón devría mostrar más pena por su dueño, que ya no es parte para tenerse en la silla después que vuestra hermosura vio» (Fernández 2013: III, 284). El caballero es capaz de transformar las palabras descorteses de la dama en un elogio de su belleza; se comporta con elegancia cortesana al desviar el asunto de la crítica, que no deja de ser un modo de apartarla de la conversación ${ }^{33}$. En otras palabras, no cae en la provocación e inicia otra línea de diálogo que le interesa más. Aquí Belianís no está mostrando su amor por la dama, no está interesado en conseguir sus favores amorosos, sino que está iniciando un juego cortesano a partir de las críticas sobre su montura. Puede entenderse una cierta ironía, sin duda, pero no considero que deba entenderse como un insulto a la hermosura de la dama, no creo que Belianís la esté llamando fea, sino que, ante la imposibilidad de mostrar su carácter cortesano en su aspecto, lo hace en su expresión verbal. A pesar de sus esfuerzos, la conversación continúa por

31. Río Nogueras comentó que en «ese nuevo decorado áulico al caballero se le presentan celadas verbales que debe resolver en términos de desenvoltura cortesana» (Río Nogueras 1993: 74).

32. Los donaires cortesanos y los diálogos cargados de humor son frecuentes en los libros de caballerías, lo que es una muestra más de cómo la imagen del perfecto caballero implica su faceta como cortesano. Sobre este aspecto Martín Romero 2007: 83-89.

33. El caballero no responde a la injuria con más insultos. Guevara indicaba que «Más es de mujeres, que no de hombres, querer vengar palabras con palabras» (fol. $88^{\mathrm{r}}$ ). No obstante, en otras ocasiones sí observamos esa actitud, precisamente cuando se abandona el carácter cortesano. 
la vía de la crítica; cuando el héroe finalmente se ve obligado a luchar contra los caballeros que acompañan a la mujer, continúa con el juego cortesano del servicio amoroso y le pide licencia para hacerlo: «Mi seńora, ¿daysme licencia para que prueve mi ventura con estos cavalleros?» (Fernández 2013: III, 286); pero añade: "con el favor de vuestra hermosura, no sería mucho dar una buena caýda al primero encuentro» (Fernández 2013: III, 286). Aquí la ironía llega de forma plena, el favor de su hermosura no lo librará de ser desarzonado, lo que implica que no es un apoyo suficiente.

Ese carácter de divertimento de la expresión cortesana continuará. Belianís juega verbalmente a ser el caballero de la dama que se burla de él. En un determinado momento, Belianís de Grecia se dispone a entrar en un torneo cuando un escudero de esta dama le entrega una lanza de parte de su seńora con las siguientes palabras: "pues por su servicio havéys de entrar en este torneo, vos plega de llevar esta lança; y, porque tengáys entendido que no está olvidada de vuestros amores, ella por su mesma mano ha bordado este tan rico pendón después que de vos se partió; y que tengáys buena confiança, que a cavallero que tan altos amores como los suyos ossa emprender, todas las aventuras se le deven» (Fernández 2013: III, 296). El lenguaje propio del amor cortés en este caso no es sino burla cortesana que el héroe sigue en su respuesta: «Dezidle, gentil escudero, a mi señora -respondió el príncipe- que, con tan gran favor, acabar todas las cosas será poco, y que el mayor descontento que tenía era pensar que estava ausente de su memoria» (Fernández 2013: III, 296). El comportamiento del héroe se adecúa a las normas del fin' amors, pero en este caso no es más que una broma cortesana: no hay lugar a dudas, cuando el escudero vuelve le cuenta a su señora lo sucedido y «la respuesta del cavallero, de que mucho rieron» (Fernández 2013: III, 296).

La gracia es una de las virtudes que debe adornar a todo noble. Antonio Beccadelli o Panormitano, en De los dichos y hechos del rey don Alonso no olvidó ese aspecto al incluir numerosas ocurrencias y sentencias en las que el monarca se revelaba como "gracioso", lo que evidencia que el cortesano servidor, en este punto, no solo debía serlo para agradar a su señor, sino también para imitar sus costumbres cortesanas ${ }^{34}$. Las palabras de Belianís se corresponden, además, con algunas de las indicaciones que Castiglione recogió en su tratado respecto a los dichos graciosos: «Harto gracioso y de buen arte es también lo que consiste en una cierta disimulación cuando se dice una cosa y debaxo de aquélla se entiende otra [...]; cuando, con un hablar mesurado y grave, burlando, dice el hombre sabrosamente lo que no tiene en el corazón» (202). Es más, el italiano indicaba que se trataba de una forma adecuada para los personajes de cierta relevancia: "Esta forma de decir gracias que alcanza esta manera de ironía o disimulación parece muy conveniente a hombres de autoridad, porque es grave y tiene gusto, y puédese usar en las burlas y en las veras» (203).

34. Se ha de señalar que Beccadelli incluye toda una serie de matices: «estudioso y gracioso», «templado y gracioso», "cathólico, piadoso y gracioso», "gracioso y grave» y "gracioso y bien criado». Esto indica que las gracias se adecúan a diversas situaciones y revelan diferentes aspectos del hablante. 
El juego verbal y el ingenio en el empleo de las palabras revelan el carácter lúdico de la situación. Esas costumbres o hábitos dialogales se evidencian en momentos en los que incluso cuando se llega al insulto, se hace sin utilizar palabras directas. Así sucede, por poner un ejemplo, en una ocasión en que uno de los personajes, Brianel, se ofrece a indicar a otro caballero el paradero de Belianís si le dice quién es. Cuando este se identifica como el Caballero de los Leones, Brianel le pide más datos, pues con el sobrenombre no le basta. La respuesta del Caballero de los Leones se aleja de lo cortesano, precisamente porque considera que ha sido tratado fuera de mesura, pues no han cumplido lo pactado: «Desmesurado soys - dixo el Cauallero de los Coronados Leones-, auiéndoos dicho yo mi nombre no me dezir lo que os pregunto, que si no me conocéys no hera yo obligado a deziros quién fue mi agüelo» (Fernández 1997: I, 274). A esto no responde Brianel, sino su compañero Palineo, con una ironía que se acerca más a la pulla cortesana: «No es marauilla -respondió Palineoque no seáys conocido auiendo acabado tantas cosas con essas armas, según las trahéys cortadas por muchas partes no fuera mucho que sin más preguntar fuérades conocido y estuuiera el reyno de Antiocha lleno de vuestras hazañas» (Fernández 1997: I, 274). Se trata de una antífrasis: las armas del caballero no están "cortadas por muchas partes», sino en perfectas condiciones, lo que indica que no ha luchado con ellas. Poco antes Palineo ya había señalado que esto le hacía pensar que se trataba de un caballero novel (Fernández I: 273). La respuesta del Caballero de los Leones a Palineo también resulta mordaz e insinúa que quizá él lleva armas maltratadas y golpeadas no porque haya sufrido en batallas, sino tan solo para dar la falsa sensación de que lo ha hecho: «Según vuestras palabras -dixo el de los Leones-, más pienso que por no parecer otro tanto como yo dezís que parezco, trahéys las vuestras cortadas, que no porque ayáys entrado con ellas en alguna batalla» (Fernández 1997: I, 274-275).

Estos comentarios, aunque expresados con un tono que los aleja de la mesura cortesana, recogen plenamente las indicaciones de Castiglione sobre «los dichos graciosos para picar» (197). Especialmente la antífrasis de Palineo se vincula con el ingenio cortesano que evita la expresión directa de la idea. Cierto es que el italiano se refería a situaciones agradables y rechazaba cualquier tipo de insulto o injuria, a diferencia de lo que vemos aquí; pero no se puede negar que nos encontramos ante un empleo verbal que responde a los mismos mecanismos retóricos propugnados por el italiano y que se explican en boca de personajes acostumbrados a servirse de esas herramientas retóricas. Por otra parte, no hay que olvidar que las indicaciones de Castiglione iban dirigidas al cortesano servidor, mientras que los personajes de libros de caballería no han de plegarse a esas mismas condiciones (no son siervos). Puede entenderse que el ingenio de Palineo y del Caballero de los Leones es el que han de imitar los cortesanos, quienes deben evitar caer en el insulto para no resultar desagradables.

De hecho, en ocasiones la cortesanía no es sino una herramienta al servicio de unos determinados intereses, esto es, se explica desde el pragmatismo. Eso 
sucede cuando Belianís solicita a un caballero amigo suyo (don Serafín de España) que no luche con tanto ahínco en un determinado torneo, pues eso le puede acarrear consecuencias indeseadas: «Esforçado cavallero, no deys causa que las cosas de plazer se buelvan al revés; $y$, si pretendéys en esta corte rescebir honra, no lo comencéys con su contrario, que no es esta batalla campal para llegarla tan al fin» (Fernández 2013: III, 300). Belianís le recuerda que sus logros en el torneo lograrán humillar a los caballeros de la corte en la que pretenden recibir honra. Su éxito provocará odio por parte de quienes han sido derrotados -los caballeros «cortesanos», es decir, los del lugar-. Don Serafín reconoce el valor pragmático de la recomendación de Belianís («Gran merced, señor cavallero - dixo el infante-, por el buen consejo», Fernández 2013: III, 300). El mismo consejo le había dado a otro amigo suyo, Ariobarzano, a quien, sin embargo, le expuso la idea de forma más sofisticada: «Soberano príncipe, dad lugar a los otros que puedan tornear, que vuestro valor ya está conocido» (Fernández 2013: III, 300).

En definitiva, en Belianis de Grecia los personajes muestran su cortesanía verbal en parlamentos de cierta complejidad sintáctica, con juegos de palabras -que en ocasiones recuerdan a los de la poesía cancioneril-, apoyados en el doble sentido de una palabra, en el asteísmo, en la hipérbole y en otros recursos orientados a mostrar el propio ingenio y separase así del modo de hablar «villano». No es de extrañar, por tanto, que estas formas de conversar fueran asumidas como ejemplos de cortesanía en la realidad histórica.

\section{VARIANTES EN LA CORTESANÍA}

En cualquier caso, también existe diversidad de opiniones en relación a lo que se ha de considerar cortesano; recordemos el testimonio de Pedro Mexía, que no veía con buenos ojos lo de quitarse el bonete para saludar, porque era "cosa muy trabajosa», como confiesa en su Silva de varia lección (Granja: 12). Por otra parte, también el tiempo hacía mella en estos usos y hábitos, algo que señaló Castiglione: «la costumbre hace que muchas veces una misma cosa nos parezca bien y agora mal; por do suele acontecer que los usos, las costumbres, las cerimonias y los modos que en un tiempo estuvieron en mucha estima vengan a ser despreciados, y por el contrario, los despreciados vengan a ser tenidos en muy gran precio» (77).

Junto a la diversidad de opinión y los cambios de moda, hubo además diferencias entre nacionalidades diversas: Castiglione fue también consciente de que las diversas normas pragmáticas de cada lengua regían el comportamiento, como se observa en sus comentarios sobre franceses y españoles; sobre los primeros decía que "tienen una cierta libertad y una conversación suelta» (160), pero explica que ello «es natural a toda aquella nación; así que por eso no se deben llamar soberbios ni locos porque ya es su arte aquélla» (160). A principios del siglo XVII Carlos García en La oposición y conjunción de los dos grandes luminares de la tierra o la antipatía de franceses y españoles comparaba 
los modales de las dos nacionalidades, ciertamente diversos en cuanto a las relaciones entre los sexos:

si le preguntamos a un español qué le parece del modo y costumbre que los franceses tienen en saludar las damas, besándoles el rostro, allegándose a ellas y tocándolas, con la desenvoltura y libertad que se pratica en Francia, verdaderamente perderá los estribos de la paciencia, y será del todo imposible podelle persuadir que la tal ceremonia tenga algo de civil y cortés, siendo máxima entre ellos que quien escucha dará la mano, y quien da la mano dará el rostro, y con el rostro, todo. (García: 204, tomo la cita de Granja: 12-13)

Se trata justamente de todo lo contrario a las normas españolas que propugnaban evitar en lo posible el contacto entre personas de distinto sexo, al menos a juicio de un viajero italiano que pasó por Córdoba en 1668 y que se sorprendía de este hecho (lo que, a su vez, demuestra las diferencias entre Italia y España al respecto): «la mayor fineza que se pueda tener con una dama es, cuando se tiene tiempo, rehuir el encuentro con su carroza; y no pudiendo rehuirla, volverse, cuando pasa, hacia el otro lado, para no obligarla con el saludo a devolverlo» (Guzmán Reina: 101, tomo la cita de Granja: 12) ${ }^{35}$.

En definitiva, al igual que en la realidad, también en los libros de caballerías las diferencias son notables y no sólo de matiz. El análisis de la cortesanía en estos textos revela todo un abanico de actitudes, comportamientos y formas de realización. Por otra parte, en relación a la expresión verbal no hay que olvidar las singularidades estilísticas de cada autor; los complicados juegos verbales de la conversación cortesana eran un terreno propicio para lucir sus habilidades literarias (al igual que las glosas, los amaneceres mitológicos, las cartas o las arengas). Por ello, el estilo personal de cada escritor ha de tenerse en cuenta a la hora de valorar las palabras de los personajes de estos libros.

Por otra parte, hay que señalar que ni todos estos personajes se muestran como cortesanos ni, quienes lo son, se comportan en todo momento como tales. El análisis de su expresión revela la diversidad de personalidades que encontramos en estos libros, y nos da pistas sobre sus diversos estados de ánimo, sus respuestas emocionales y su evolución psicológica. Esas divergencias aumentan si se comparan distintos libros, en los que los modales cortesanos no siempre coinciden. Por ello se hace necesario determinar la manera como en cada título caballeresco se proponen modelos de comportamiento cortesano y comprobar, dentro de cada título, cómo esa cortesanía esconde en muchos casos una humanidad palpitante y real de sus personajes.

El análisis de estos aspectos en los libros de caballerías nos dice mucho de la sociedad y el pensamiento de la época. Es sabido que su carácter eminentemente fabuloso no impide que en no pocos de ellos haya guiños al momento histórico e incluso en algún caso se escondan lecturas en clave. Hemos comprobado que la realización de las normas cortesanas en Belianís

35. Atender a estas divergencias nacionales de uso y costumbre quizá sirva para comprender determinados cambios en la traducción a otras lenguas. 
no se aleja de lo propuesto por los tratados de la época, lo que nos indica que no sólo se recibían como ficciones gustosas y artificiosas, sino también como modelos de comportamiento. Es lógico pensar que su influencia en la realidad histórica va mucho más allá de la inspiración de torneos y justas caballerescas y que alcanzó también a los ámbitos cortesanos funcionando como verdaderos espejos de cortesanía. Por ello, el conocimiento de los comportamientos y usos sociales en los libros de caballerías iluminará el que tengamos de la sociedad de esos años.

\section{Bibliografía}

Baranda Leturio Nieves, 1995, "Gestos de la cortesía en tres libros de caballerías de principios del siglo XVI», en Les traités de savoir-viure en Espagne et en Portugal du Moyen Âge à nos jours, Clermont-Ferrand, Association des Publications de la Faculté des Lettres et Sciences Humaines de Clermont-Ferrand, 55-68.

Barber Richard, 1995, The knight and chivalry, The Boydell Press, Woodbridge, 415 pp.

Beccadelli Antonio, 2000, Dichos y hechos del rey don Alonso (1527), ed. de Olga Muñoz, Revista Lemir 4, recuperado el 5 de marzo de 2020 de http://parnaseo. uv.es/Lemir/Textos/Dichos/Index.htm

Bognolo Anna, 1995, «La entrada de la realidad y de la burla grotesca en un libro de caballerías: el Lepolemo, Caballero de la Cruz (Valencia, 1521)», en Juan Paredes Núñez (ed.), Granada, Medioevo y Literatura. Actas del V Congreso de la Asociación Hispánica de Literatura Medieval (Granada, 27 septiembre - 1 octubre 1993), Granada, Universidad de Granada, T. 1, 371-378.

Byles A. T., 1928, «Medieval Courtesy Books and Prose Romances of Chivalry», en E. Prestage (ed.), Chivalry. A series of studies to illustrate its historical Significance and civilizing influence, Londres, Kegan Paul, Trench, Trubner \& Co., 183-206.

Camos Marco Antonio de, 1592, Microcosmia y gobierno universal del hombre christiano para todos los estados y qualquiera de ellos, Barcelona, Pablo Malo, 719 pp.

Cartagena Alonso de, 1983, El oracional, ed. de Silvia González-Quevedo Alonso, Valencia, Albatros Hispanófila, 232 pp.

Castiglione Baltasar de, 1984, El Cortesano, ed. de Rogelio Reyes Cano, Madrid, Espasa-Calpe, 1984. 357 pp.

Clemente Dionís, 2010, Valerián de Hungría, ed. de Jesús Duce, Alcalá de Henares, Centro de Estudios Cervantinos, col. «Libros de Rocinante», 743 pp.

Covarrubias Horozco Sebastián de, 2006, Tesoro de la lengua castellana o española, ed. de Ignacio Arellano y Rafael Zafra, Madrid, Universidad de Navarra-IberoamericanaVervuert, Real Academia Española-Centro para la Edición de Clásicos Españoles, 1644 pp.

Crouch David, 2005, Tournament, Hambledon and London, Londres, 235 pp.

Elias Norbert, 1993, El proceso de civilización. Investigaciones sociogenéticas y psicogenéticas, México, Fondo de Cultura Económica, 581 p.

Frappier Jean, 1973, Amour courtois et Table Ronde, Genève, Droz, 308 pp. 
Fernández Jerónimo, 1997, Belianís de Grecia, introd., texto crítico y notas de Lilia E. F. de Orduna, Kassel, Reichenberger, 2 vols., 431 pp y 531 pp.

Fernández Jerónimo, 2013, Belianis de Grecia (Tercera y Quarta Parte), en Laura Gallego (ed.), Belianis de Grecia (Tercera y Quarta Parte) de Jerónimo Fernández: edición y estudio, tesis doctoral dirigida por Rafael Beltrán Llavador, Valencia, Universitat de València, $942 \mathrm{pp}$.

García Carlos, 1979, La oposición y conjunción de los dos grandes luminares de la tierra o la antipatía de franceses y españoles [París, 1617], ed. Michel Bareau, Edmonton, Alba Press, 376 pp.

González Javier Roberto, 2000, «Los límites de la cortesía: amor y poder en el AmadisSergas", en Melchora Romanos (coord.) y Melchora Romanos y Florencia Calvo (ed.)., Lecturas críticas de textos hispánicos. Estudios de literatura española. Siglo de Oro, vol. 2, Buenos Aires, Eudeba-Instituto de Filología y Literaturas Hispánicas «Dr. Amado Alonso»-Universidad de Buenos Aires, 69-78.

González Ollé Fernando, 2002, «El habla cortesana, modelo principal de la lengua española», Boletín de la Real Academia Española, 82: 286. 153-231.

Granja Agustín de la, 2013, «Ronda y galanteo en la Espańa del Siglo de Oro», en Roberto Castilla Pérez (ed.), Ronda, cortejo y galanteo en el teatro español del Siglo de Oro, Universidad de Granada, Granada, 11-28.

Guevara Antonio de, 1579, Libro llamado aviso de privados y doctrina de cortesanos, Pamplona, Tomás Porralis, 177 fols.

Guzmán Reina Antonio, 1966, Córdoba, siglo XVII, Málaga, Librería anticuaria «El Guadalhorce», 114 pp.

Haverkate Henk, 1994, La cortesía verbal: estudio pragmalingüistico, Madrid, Gredos, 245 pp.

Laspalas Pérez Francisco Javier, 2006, «El problema de la insinceridad en cuatro tratados de cortesía del Renacimiento» en Rocío García Bourrellier y Jesús María Usunáriz Garayoa (coords.), Aportaciones a la historia social del lenguaje: España, siglos XIV-XVIII, Madrid-Frankfurt am Main, Iberoamericana-Vervuert, 27-56.

Lewis C. S., 1985, The Allegory of Love. A study in medieval tradition, Oxford, New York, Oxford University Press, 378 pp.

Ly Nadine, 1981, La poétique de l'interlocution dans le théatre de Lope de Vega, Bordeaux, Institut d'Études Ibériques et Ibéro-Américaines de l'Université de Bordeaux, 363 pp.

Marín Pina, M. ${ }^{a}$ Carmen, 1988, «Las cartas de amor caballerescas como modelos epistolares», en Jean Pierre Etienvre y Leonardo Romero Tobar (coords.), La recepción del texto literario, Zaragoza/Madrid, Universidad de Zaragoza/Casa de Velázquez, 11-24.

Martín Romero José Julio, 2007, Entre el Renacimiento y el Barroco. Pedro de la Sierra y su obra, Zaragoza, Prensas Universitarias de Zaragoza, 337 pp.

Martín Romero José Julio, 2008a, "La "verdad disimulada” y el "juramento ambiguo" en la literatura caballeresca", en Amadis de Gaula: quinientos años después. Estudios en homenaje a Juan Manuel Cacho Blecua, eds. José Manuel Lucía Megías; María Carmen Marín Pina; col. Ana Carmen Bueno, Alcalá de Henares, Centro de Estudios Cervantinos, 503-523. 
Martín Romero José Julio, 2008b, «Del fin’amors al neoplatonismo: amor y caballería en la narrativa caballeresca hispánica», Tirant. Butlletí informatiu i bibliogràfic de la literatura de cavalleries, 11. 119-142.

Martín Romero José Julio, 2010, «Fidelidad sentimental y catarsis amorosa en el ciclo de Amadis de Gaula», Revista de Literatura Medieval, 22. 155-184.

Martín Romero José Julio, 2014, «Palmerín de Olivia como enmienda del modelo amadisiano: El rechazo de la perfección arquetípica», Revista de Literatura, 76:152. 427-447.

Martín Romero José Julio, 2015a, «Heridas, sangre y cicatrices en Belianís de Grecia: las proezas del héroe herido", en Marta Haro Cortés (ed.), Literatura y ficción: "estorias", aventuras y poesía en la Edad Media. Actas del Coloquio Internacional de la Asociación Hispánica de Literatura Medieval (Universidad de Valencia, 19 al 21 de noviembre de 2014), Valencia, PUV, T. 2, 563-577.

Martín Romero José Julio, 2015b, «Psicología, pragmatismo y motivaciones encubiertas en el universo caballeresco en Palmerín de Olivia», en Carlos Alvar (coord.), Estudios de literatura medieval en la Península Ibérica, San Millán de la Cogolla, CILENGUA, 941- 954.

McIntosh Carey, 1986, Common and Courtly Language: The Stylistics of Social Class in 18th Century British Literature, Philadelphia, University of Pennsylvannia Press, $144 \mathrm{pp}$.

Milán Luis, 1874, Libro intitulado el Cortesano, «Col. de libros españoles raros o curiosos», Madrid, Aribau, 502 pp.

Morreale Margherita, 1958-1959, "El mundo del cortesano», Revista de Filología Española, 42: 1/4. 229-260.

Núñez de Castro Alonso, 1658, Libro histórico político. Solo Madrid es corte y el cortesano en Madrid, Madrid, Andrés García de la Iglesia. 140 fols.

Orduna Portús Pablo Miguel, 2006, «El silencio de la Corte. El 'Arte de Callar' y sus formas de conducta en el ámbito social cortesano, siglos XVI, XVII y XVIII», en Rocío García Bourrellier y Jesús María Usunáriz Garayoa (coords.), Aportaciones a la historia social

del lenguaje: España, siglos XIV-XVIII, Madrid-Frankfurt Am Main, IberoamericanaVervuert, 57-84.

Palencia Antonio de, 1490, Universal vocabulario en latín y en romançe, Sevilla, Paulus de Colonia cum suis sociis [=Johannes Pegnitzer, Magnus Herbst et Thomas Glockner]. T. I, 248 fols., t. II, 542 fols.

Panormitano Antonio, 1527, De los dichos y hechos del Rey don Alonso, Valencia, Juan Joffre, 70 fols. (edición facsímil: Vicent García Editores, 1992)

Place Edwin B., 1954, "El Amadis de Montalvo como manual de cortesanía en Francia», Revista de Filología Española, 38: 1/4. 151-169.

Quondam Amedeo, 2013, El discurso cortesano, ed. de E. Torres Corominas, Madrid, Polifemo, $462 \mathrm{pp}$.

Ravasini Ines, 2010, "Crónica social y proyecto político en El Cortesano de Luis Milán», Studia Aurea: Revista de Literatura Española y Teoría Literaria del Renacimiento y Siglo de Oro, 4. 69-92. 
Ricci Maria Teresa, 2013, «La 'Cortegiania' e la 'Cortesana Filosofia': B. Castiglione e B. Gracián», Revista de Italianistica, 25. 36-50.

Rígano Mariela E., 2000, «Fórmulas de tratamiento y cortesía en las relaciones amorosas de la novela de caballería (siglo XVI)», Cuadernos del Sur-Letras, 30. 139-166.

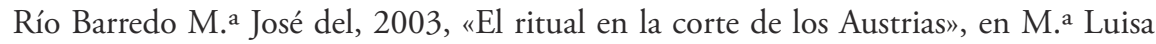
Lobato; Bernardo J. García y García (coords.), La fiesta cortesana en la época de los Austria, Valladolid, Junta de Castilla y León, 17-34.

Río Nogueras Alberto del, 1993, «Del caballero medieval al cortesano renacentista. Un itinerario por los libros de caballerías», en Actas IV Congresso Asociación Hispánica de Literatura Medieval, Lisboa 1991, Lisboa, Cosmos, t. II, 73-80.

Río Nogueras Alberto del, 1995, "Sobre magia y otros espectáculos cortesanos en los libros de caballerías», en Juan Paredes (ed.), Medioevo y Literatura. Actas del V Congreso de la Asociación Hispánica de Literatura Medieval (Granada, 27 septiembre 1 octubre 1993), Granada, Universidad de Granada, t. IV, pp. 137-149.

Río Nogueras Alberto del, 2004, "Libros de caballerías y burlas cortesanas. Sobre algunos episodios del Cirongilio de Tracia y del Clarián de Landanís», en Javier Gómez-Montero y Bernhard König (dir.); Folke Gernert (ed.), Letteratura cavalleresca tra Italia e Spagna (da «Orlando» al "Quijote»). Literatura caballeresca entre España e Italia (del

«Orlando» al «Quijote»), Salamanca, Seminario de Estudios Medievales y Renacentistas, Sociedad de Estudios Medievales y Renacentistas, Kiel, CERES de la Universidad de Kiel, 53-65.

Rodilla María José, 2005, «Gestos áulicos y espectáculos palaciegos: Las ceremonias cortesanas y guerreras en el Claribalte de Fernández de Oviedo», en María José Rodilla; Alma Mejía, eds., Memoria y Literatura. Homenaje a José Amezcua, México, Universidad Autónoma Metropolitana, 115-125.

Snyder Jon R., 2009, Dissimulation and the Culture of Secrecy in Early Modern Europe, University of California Press, Berkeley/Los Angeles/London, 280 pp. 